\title{
PEMANFAATAN TEPUNG SUKUN (Artocarpus altilis sp.) PADA PEMBUATAN ANEKA KUDAPAN SEBAGAI ALTERNATIF MAKANAN BERGIZI UNTUK PMT-AS
}

\author{
(Utilization of Breadfruit [Artocarpus altilis sp.] Flour in Production of Snacks as Nutritious Foods for \\ School Supplementary Feeding Programme)
}

\author{
Dewanti Putri Pratiwi ${ }^{1 *}$, Ahmad Sulaeman ${ }^{1}$, dan Leily Amalia ${ }^{1}$ \\ 'Departemen Gizi Masyarakat, Fakultas Ekologi Manusia (FEMA), Institut Pertanian Bogor, \\ Jl. Raya Darmaga, Bogor 16880
}

\begin{abstract}
Breadfruit is valuable fruit and has a good of nutrient content, but its usage is limited by poor storage properties of fresh fruit. Processing into flour, can increase its utilization. The aim of this research was to utilize breadfruit flour in production of nutritious snack foods for School Supplementary Feeding Programme (PMT-AS). There were three products developed in this study; brownies, pia, and croquette. The research was conducted using experimental design. The proportions of breadfruit flour and wheat flour were different for each product, which brownies was formulated using 70:30, 80:20, 90:10, and 100:0; whereas pia and croquette was formulated by 50:50, 60:40, 70:30, and 80:20. Proximate analysis showed that $100 \mathrm{~g}$ brownies contained $409 \mathrm{kcal}$ energy and $7.5 \mathrm{~g}$ protein, $100 \mathrm{~g}$ pia had $383 \mathrm{kcal}$ energy and $6.7 \mathrm{~g}$ protein and croquette had the highest energy and protein content is $455 \mathrm{kcal}$ and $9.9 \mathrm{~g}$ protein. In conclusion, all products were suitable as alternative snacks for PMT-AS. The products have met $300 \mathrm{kcal}$ energy and $5 \mathrm{~g}$ protein per serving size. Considered also the cost of production, these products have fulfilled criteria to be used in PMT-AS.
\end{abstract}

Keywords: breadfruit, PMT-AS, snacks

\begin{abstract}
ABSTRAK
Sukun merupakan buah yang bernilai dan memiliki kandungan gizi yang baik, tetapi penggunaannya terbatas oleh penyimpanan ketika berbentuk buah segar. Sukun yang diubah ke dalam bentuk tepung dapat meningkatkan pemanfaatannya. Tujuan dari penelitian ini adalah memanfaatkan tepung sukun dalam pembuatan kudapan sebagai alternatif makanan bergizi untuk PMT-AS. Terdapat tiga produk dalam penelitian ini, yaitu brownies, pia, dan kroket. Penelitian ini menggunakan desain eksperimental. Perbandingan tepung sukun dan tepung terigu berbeda untuk masing-masing produk. Formulasi brownies adalah 70:39, 80:20, 90:10, dan 100:0, sedangkan formulasi pia dan kroket adalah 50:50, 60:40, 70:30, dan 80:20. Berdasarkan uji organoleptik diketahui bahwa produk terpilih adalah brownies dengan $90 \%$ tepung sukun, pia dengan $60 \%$ tepung sukun, dan kroket dengan $60 \%$ tepung sukun. Seluruh produk telah sesuai sebagai alternatif kudapan untuk PMT-AS. Produk-produk tersebut juga telah memenuhi 300 kkal energi dan $5 \mathrm{~g}$ protein per serving size.
\end{abstract}

Kata kunci: kudapan, PMT-AS, sukun

"Korespondensi: Departemen Gizi Masyarakat, Fakultas Ekologi Manusia (FEMA), Institut Pertanian Bogor, Jl. Raya Darmaga, Bogor 16880; Email: dewantippra@gmail.com 
Pratiwi dkk.

\section{PENDAHULUAN}

Berkaitan dengan pemenuhan kebutuhan gizi anak sekolah, pemerintah telah menjalankan Program Makanan Tambahan Anak Sekolah (PMT-AS) di Sekolah Dasar (SD) dan Taman Kanak-kanak (TK) di berbagai daerah di Indonesia. PMT-AS bertujuan untuk mencegah masalah kekurangan energi dan protein pada siswa SD dan Madrasah Ibtidaiyah (MI) sekaligus upaya mengurangi kecacingan pada anak. Penyediaan makanan pada PMT-AS mencakup beberapa persyaratan dalam hal bentuk, kandungan gizi, dan bahan makanan yang digunakan. Kandungan gizi kudapan harus memenuhi 300 kkal energi dan $5 \mathrm{~g}$ protein. Syarat penggunaan bahan makanan yang digunakan salah satunya adalah menggunakan bahan hasil pertanian setempat (Tim Koordinasi PMT-AS Pusat 2010).

Sukun merupakan tanaman lokal yang penyebarannya sangat luas dan merata di daerah yang beriklim tropis, termasuk Indonesia (Taylor \& Tuia 2007). Buah sukun menjadi komoditas yang cukup penting karena produktivitasnya yang tinggi (Omobuwajo et al. 2003). Meskipun demikian, pemanfaatan buah sukun masih terbatas karena masalah penyimpanan yang sulit dalam bentuk buah segar. Oleh karena itu, salah satu upaya yang dilakukan adalah mengolahnya dalam bentuk tepung. Buah sukun yang ditepungkan memiliki nilai zat gizi yang relatif tetap dan pemanfaaatannya tidak terkendala waktu (Adebayo \& Ogunsola 2005). Pemanfaatan tepung berbahan dasar sukun diharapkan dapat menjadi salah satu alternatif pembuatan kudapan untuk PMT-AS. Pembuatan PMT-AS berbahan dasar tepung sukun diharapkan dapat menghasilkan kudapan berbahan dasar lokal yang bernilai gizi baik. Penelitian ini secara umum bertujuan untuk mengetahui pemanfaatan tepung sukun (Artocarpus altilis sp.) dalam pembuatan aneka kudapan (brownies, pia, dan kroket) sebagai salah satu alternatif makanan bergizi dalam PMT-AS.

\section{METODE}

\section{Desain, Tempat, dan Waktu}

Penelitian ini menggunakan desain eksperimental. Penelitian dilaksanakan sejak bulan Mei sampai Oktober 2012. Penelitian dilakukan di Laboratorium Percobaan Makanan, Laboratorium Kimia dan Analisis Pangan, dan Laboratorium Penilaian Organoleptik, Departemen Gizi Masyarakat, Fakultas Ekologi Manusia, Institut Pertanian Bogor. Analisis uji daya terima dilakukan di SDN Rama 1 Kota Tangerang, Banten.

\section{Bahan dan Alat}

Bahan yang digunakan dalam pembuatan tepung sukun adalah buah sukun yang berusia 15-19 minggu dan natrium metabisulfit 0.3\%. Bahan yang digunakan dalam pembuatan pia adalah tepung sukun, tepung terigu, gula kastor, kacang hijau, keju, telur, santan bubuk, margarin, garam, dan susu cair. Bahan yang digunakan dalam pembuatan brownies adalah tepung sukun, tepung terigu, telur, margarin, gula kastor, coklat bubuk, coklat batang, pasta coklat, ovalet, dan garam. Bahan-bahan dalam pembuatan kroket adalah tepung sukun, tepung terigu, wortel, ayam, kentang, susu, dan garam.

Alat-alat yang digunakan untuk pembuatan tepung adalah pisau, penggiling tepung, ayakan 60 mesh, dan oven. Alat-alat yang digunakan dalam pembuatan kudapan adalah timbangan, mixer, gelas ukur, penggiling dan pencetak adonan, kompor, dandang, pisau, sendok, dan oven.

\section{Tahapan Penelitian}

Penelitian dilakukan melalui dua tahap, yaitu penelitian pendahuluan dan penelitian lanjutan. Penelitian pendahuluan dilakukan untuk menganalisis sifat fisik dan kimia tepung sukun dan mengetahui formulasi yang tepat dalam penggunaan tepung sukun sebagai bahan dasar pembuatan kudapan basah. Penelitian lanjutan dilakukan untuk mengetahui sifat organoleptik dari formulasi terpilih, melakukan analisis zat gizi terhadap formulasi produk terpilih, dan mengetahui daya terima anak sekolah terhadap produk dengan formulasi terpilih.

\section{Rancangan Percobaan, Pengolahan, dan Analisis Data}

Rancangan percobaan yang digunakan pada penelitian ini adalah Rancangan Acak Lengkap (RAL) dengan dua kali ulangan. Perlakuan yang dilakukan pada unit percobaan adalah jumlah tepung sukun pada kudapan. Data yang diperoleh diolah dengan menggunakan program Microsoft Excel dan SPSS for Windows 16.0. Data daya terima anak sekolah terhadap produk kudapan disajikan secara deskriptif.

\section{HASIL DAN PEMBAHASAN}

\section{Pembuatan Tepung Sukun}

Tahap pembuatan tepung sukun adalah pengupasan, perendaman dengan larutan natrium metabisulfit $0.3 \%$, pengirisan, pengeringan menggunakan oven dengan suhu $60^{\circ} \mathrm{C}$ sampai mudah patah, penghalusan menggunakan blender, dan pengayakan menggunakan ayakan 60 mesh. Rendemen tepung sukun yang dihasilkan dari $36.118 \mathrm{~kg}$ adalah $20.33 \%$. Zat gizi makro tepung sukun hasil analisis dapat dilihat pada Tabel 1 berikut.

Komposisi zat gizi tepung sukun berbeda dengan penelitian sebelumnya (Widowati 2003). Hal ini dikarenakan tepung sukun analisis dibuat menggunakan metode pengeringan oven sedangkan penelitian sebelumnya menggunakan alat drum dryer. Suhu 
Tabel 1. Komposisi Zat Gizi Tepung Sukun dan Terigu (\% Bb)

\begin{tabular}{clccc}
\hline No & Zat Gizi & Tepung sukun Analisis & Tepung sukun* & Tepung terigu* \\
\hline 1 & Air & 9.2 & 15 & 11.2 \\
2 & Protein & 2.83 & 3.6 & 8.9 \\
3 & Lemak & 0.38 & 0.8 & 1.3 \\
4 & Abu & 1.9 & 2 & 1.3 \\
5 & Karbohidrat & 85.65 & 78.9 & 77.3 \\
\hline
\end{tabular}

*Sumber: Widowati (2003)

pada metode drum dryer yang lebih tinggi mengakibatkan jumlah zat gizi seperti air, lebih banyak hilang dibandingkan dengan pemanasan menggunakan oven (Olandujoye et al. 2010).

\section{Formulasi Kudapan PMT AS Berbahan Dasar Tepung Sukun}

Kudapan PMT AS dibuat sebanyak tiga buah, yaitu brownies, pia, dan kroket. Jenis kudapan dibuat dengan mempertimbangkan beberapa hal, yaitu (1) kemampuan tepung sukun mensubstitusi kudapan minimal 50\% karena kudapan yang dihasilkan harus berbahan dasar tepung sukun (2) kudapan tersebut diolah dengan cara yang berbeda (dipanggang, digoreng, dan dikukus) (3) keefektifan kudapan tersebut untuk memenuhi kebutuhan energi dan protein. Takaran saji kudapan tersebut tidak berlebihan dalam hal jumlah namun dapat mencukupi batas minimal zat gizi yang disarankan dalam pedoman PMT-AS.

Seluruh kudapan yang dibuat disubstitusi dengan tepung sukun minimal $50 \%$ sehingga kudapan yang dihasilkan diharapkan dapat berbahan dasar tepung sukun. Brownies dengan tepung sukun di atas $60 \%$ memiliki tekstur sifat sensori yang lebih baik. Penelitian yang dilakukan oleh Alice et al. (2012) juga menunjukkan bahwa tingkat substitusi di atas $50 \%$, pada produk cake akan menunjukkan perbedaan yang nyata pada kualitas sensori produk. Dengan demikian, substitusi yang dilakukan dalam formulasi brownies adalah $70 \%, 80 \%$, 90\%, dan $100 \%$. Substitusi tepung sukun dalam produk pia kacang hijau adalah 50\%, 60\%, 70\%, dan 80\%. Produk pia dengan substitusi di atas $80 \%$ menjadi kurang kompak dan tekstur kulitnya pecah setelah dipanggang. Adapun substitusi tepung sukun dalam formulasi kroket adalah 50\%, 60\%, 70\%, dan 80\%. Substitusi di atas $80 \%$ membuat produk ini menjadi lengket dan sulit untuk dibentuk. Semua formulasi ditetapkan berdasarkan proses trial and error.

\section{Hasil Uji Mutu Hedonik Kudapan}

Warna. Nilai mutu warna setiap produk yang diujikan cukup beragam. Nilai mutu warna produk berada pada kisaran 4.9-6.7 yang berarti biasa sampai gelap. Hasil sidik ragam menunjukkan bahwa perbedaan jumlah tepung sukun menyebabkan pengaruh yang nyata $(p<0.05)$ terhadap warna brownies sukun dan warna kroket, artinya semakin banyak tepung yang ditambahkan maka warna yang dihasilkan semakin gelap. Menurut Olaoye et al. (2006), warna tepung sukun lebih gelap dibandingkan tepung terigu akibat adanya senyawa flavonoid yang dimiliki sukun. Sedangkan pada produk pia, Hasil uji ragam menunjukkan bahwa penambahan tepung tidak berpengaruh nyata $(p>0.05)$ terhadap warna ketiga produk.

Aroma. Atribut aroma sukun pada ketiga produk dinilai agak lemah hingga agak kuat tergantung pada jumlah tepung sukun yang disubtitusi pada produk. Bahan utama penyusun produk juga memengaruhi aroma yang dihasilkan. Hasil uji ragam menunjukkan bahwa perbedaan jumlah tepung sukun terhadap parameter aroma sukun produk brownies dan pia tidak berpengaruh nyata $(p>0.05)$, namun demikian berpengaruh nyata $(p<0.05)$ pada produk kroket.

Rasa. Pembuatan produk untuk PMT-AS mengutamakan rasa dalam pembuatannya dibandingkan karakteristik organoleptik lainnya. Rasa pada produk brownies terbagi menjadi rasa sukun dan rasa manis. Rasa produk pia dibagi menjadi rasa sukun, rasa gurih, dan rasa manis, sedangkan rasa kroket dibagi menjadi rasa manis, gurih, dan rasa sukun. Penilaian panelis terhadap rasa sukun produk brownies adalah agak lemah. Produk pia dinilai memiliki rasa sukun yang biasa (tidak kuat dan lemah) hingga agak kuat, sedangkan produk kroket memiliki rasa sukun yang agak lemah hingga agak kuat. Hasil uji ragam menunjukkan bahwa perbedaan jumlah tepung sukun tidak berpengaruh nyata $(p>0.05)$ terhadap rasa sukun produk brownies dan pia, sedangkan pada produk kroket berpengaruh nyata $(p<0.05)$.

Rasa manis yang terdapat pada produk brownies dan pia dihasilkan oleh gula halus atau tepung gula. Tepung sukun juga menghasilkan rasa manis karena mengandung sukrosa. Rasa manis pada produk brownies biasa (rasa manis sedang) hingga agak manis, sedangkan produk pia memiliki penilaian agak manis. Hasil uji ragam menunjukkan bahwa perbedaan jumlah tepung sukun terhadap rasa manis produk brownies berpengaruh nyata $(p<0.05)$, namun demikian tidak berpengaruh nyata pada produk pia. Rasa gurih dinilai pada produk kroket dan pia. Hal ini dikarenakan adanya unsur lemak yang ditambahkan dalam jumlah yang cukup banyak pada 
kedua produk. Rasa gurih pada produk pia dinilai sedikit gurih, sedangkan produk kroket dinilai biasa. Hasil uji ragam menunjukkan bahwa tidak terdapat pengaruh yang nyata ( $p>0.05)$ antara penambahan tepung dengan rasa gurih produk pia, namun demikian terdapat pengaruh yang nyata $(p<0.05)$ pada produk kroket.

Tekstur. Parameter tekstur yang digunakan dalam setiap produk dalam penelitian ini adalah keempukan. Produk brownies dan produk pia memiliki nilai mutu tekstur lunak hingga agak lunak, sedangkan produk kroket memiliki nilai mutu tekstur biasa hingga agak keras. Penilaian lunak pada produk pia, brownies, dan kroket tidaklah sama. Hal ini dikarenakan panelis menilai tekstur berdasarkan standar masing-masing produk. Hasil uji ragam menunjukkan bahwa penambahan tepung sukun terhadap masingmasing formula tidak berpengaruh nyata $(p>0.05)$ terhadap tekstur brownies, sedangkan pada produk pia dan kroket berpengaruh nyata $(p<0.05)$.

\section{Hasil Uji Hedonik Kudapan}

Warna. Penilaian panelis terhadap kesukaan warna produk brownies adalah agak suka sampai suka, sedangkan panelis menilai biasa hingga agak suka untuk warna produk pia dan biasa hingga suka pada produk kroket. Hasil uji ragam menunjukkan bahwa penambahan tepung sukun tidak memengaruhi $(p>0.05)$ kesukaan panelis terhadap warna produk brownies dan pia, sedangkan pada produk kroket berpengaruh nyata $(p<0.05)$. Brownies yang disukai panelis adalah yang berwarna agak gelap, sedangkan produk kroket yang disukai panelis adalah yang berwarna gelap. Produk pia yang disukai panelis adalah yang berwarna gelap tidak pucat juga tidak (biasa).

Aroma. Penilaian panelis pada uji hedonik untuk atribut aroma ketiga produk menunjukkan hasil yang beragam. Produk brownies memiliki aroma yang agak disukai sampai disukai, sedangkan produk pia memiliki penilaian agak tidak suka sampai biasa. Aroma produk kroket dinilai biasa sampai agak suka. Hasil uji ragam menunjukkan bahwa perlakuan berpengaruh nyata $(p<0.05)$ terhadap tingkat kesukaan aroma produk brownies dan kroket, namun demikian tidak berpengaruh nyata $(p>0.05)$ pada tingkat kesukaan terhadap produk pia. Berdasarkan penilaian panelis produk brownies yang paling disukai adalah yang beraroma sukun agak lemah, sedangkan produk kroket yang disukai adalah yang beraroma sukun agak kuat. Produk pia yang paling disukai panelis adalah yang memiliki aroma biasa.

Rasa. Uji hedonik menunjukkan bahwa kesukaan panelis terhadap rasa produk brownies adalah agak suka sampai suka, sedangkan terhadap rasa produk pia adalah agak tidak suka sampai biasa (suka tidak, tidak suka juga tidak). Rasa produk kroket dinilai biasa hingga agak suka. Hasil uji ragam menunjukkan bahwa formulasi tepung sukun tidak berpenga-ruh nyata $(p>0.05)$ terhadap tingkat kesukaan rasa pada produk brownies dan pia, namun demikian berpengaruh nyata $(p<0.05)$ pada produk kroket. Produk brownies dengan rasa yang paling disukai panelis memiliki rasa sukun agak lemah dan agak manis. Produk pia yang paling disukai adalah yang memiliki rasa sukun biasa, agak terasa sedikit gurih dan agak terasa sedikit manis. Produk kroket yang paling disukai adalah yang memiliki rasa sukun biasa (tidak lemah dan tidak kuat) dan rasa gurih yang agak kuat.

Tekstur. Penilaian panelis terhadap tekstur produk brownies adalah agak suka hingga suka, sedangkan untuk produk kroket dan produk pia adalah agak tidak suka hingga biasa. Hasil uji ragam menunjukkan bahwa tekstur pada masing-masing formulasi berpengaruh nyata $(p<0.05)$ terhadap tingkat kesukaan produk brownies dan kroket, sedangkan pada produk pia tidak berpengaruh nyata. Brownies yang paling disukai panelis adalah bertekstur lunak, sedangkan produk pia yang paling disukai adalah yang bertekstur agak lunak. Panelis menyukai produk kroket yang bertekstur biasa hingga agak keras.

\section{Analisis Zat Gizi Kudapan Formulasi Terpilih}

PMT-AS memiliki persyaratan khusus untuk kudapan yang disajikan. Kandungan gizi makanan kudapan harus mengandung minimal 300 kkal dan $5 \mathrm{~g}$ protein untuk setiap hari pelaksanaan PMT-AS. Produk PMT-AS berbahan tepung sukun yang telah diuji organoleptik dipilih berdasarkan kesukaan panelis terhadap atribut rasa. Hal ini dikarenakan pada anak usia sekolah rasa merupakan atribut sensori yang paling diterima.

Produk brownies yang terpilih berdasarkan atribut sensori rasa adalah dengan $90 \%$ tepung sukun. Produk pia dan produk kroket terpilih adalah yang memiliki tingkat substitusi tepung sukun $60 \%$ terhadap tepung terigu. Produk yang terpilih kemudian dianalisis zat gizi. Tabel 2 menyajikan data hasil analisis zat gizi produk terpilih per $100 \mathrm{~g}$.

Hasil penelitian menunjukkan bahwa kadar abu dan karbohidrat produk olahan tepung sukun lebih tinggi dibandingkan tepung terigu. Kadar abu yang lebih tinggi menunjukkan kandungan mineral produk berbahan dasar tepung sukun lebih tinggi dibandingkan produk olahan tepung terigu. Tepung sukun juga merupakan sumber karbohidrat yang baik dimana $60 \%$ nya terdiri dari pati (Oladunjoye et al. 2010). Karbohidrat pada tepung sukun juga terdiri dari sukrosa (415 mg) yang memberikan karakteristik manis pada tepung sukun (Golden \& Williams 2010). Nilai protein dan lemak produk dengan substitusi tepung sukun lebih rendah dibandingkan tepung terigu, hal ini sejalan dengan penelitian yang dilakukan Akanbi et al. (2011) mengenai substitusi tepung sukun pada produk mi yang menunjukkan bahwa semakin tinggi 
Tabel 2. Data Zat Gizi Kudapan Berbahan Dasar Tepung Sukun per $100 \mathrm{~g}$

\begin{tabular}{llcccccc}
\hline & & \multicolumn{7}{c}{ Produk Kudapan } \\
\cline { 3 - 8 } No & Zat Gizi & $\begin{array}{c}\text { Brownies } \\
\text { sukun }\end{array}$ & Brownies & $\begin{array}{c}\text { Pia } \\
\text { sukun }\end{array}$ & Pia & $\begin{array}{c}\text { Kroket } \\
\text { sukun }\end{array}$ & Kroket \\
\hline 1 & Energi (kkal) & 409 & 416 & 383 & 388 & 455 & 464 \\
2 & Protein (g) & 7.5 & 10.5 & 6.7 & 9 & 9.9 & 13.4 \\
3 & Karbohidrat (g) & 45.2 & 39 & 59.2 & 52 & 47.9 & 44.2 \\
4 & Lemak (g) & 22 & 24.2 & 13.3 & 16 & 24.8 & 26 \\
5 & Air (\%) & 23.2 & 25.1 & 12.06 & - & 18.97 & - \\
6 & Abu (\%) & 2.13 & 1.2 & 1.84 & - & 5.22 & - \\
\hline
\end{tabular}

Tabel 3. Jumlah Energi dan Protein Kudapan per Takaran Saji

\begin{tabular}{|c|c|c|c|c|c|c|c|}
\hline \multirow[t]{2}{*}{ No } & \multirow[t]{2}{*}{ Jenis Kudapan } & \multicolumn{2}{|c|}{ Kontribusi Zat Gizi } & \multicolumn{2}{|c|}{ Persyaratan PMT AS } & \multicolumn{2}{|c|}{$\begin{array}{c}\text { Kontrbusi Kudapan } \\
\text { terhadap PMT AS }\end{array}$} \\
\hline & & E (kkal) & $P(g)$ & E (kkal) & $P(g)$ & E (\%) & P (\%) \\
\hline 1 & Brownies & 303 & 5.6 & 300 & 5 & 100.9 & 111.0 \\
\hline 2 & Pia & 306 & 5.4 & 300 & 5 & 102.1 & 107.2 \\
\hline 3 & Kroket & 305 & 6.6 & 300 & 5 & 101.6 & 132.7 \\
\hline
\end{tabular}

Tabel 4. Sebaran Rata-rata Daya Terima terhadap Kudapan

\begin{tabular}{|c|c|c|c|c|c|c|c|}
\hline \multirow{3}{*}{ No } & \multirow{3}{*}{ Daya Terima } & \multicolumn{6}{|c|}{ Persentase Penerimaan Kudapan (\%) } \\
\hline & & \multicolumn{2}{|c|}{ Brownies } & \multicolumn{2}{|c|}{$\mathrm{Pia}$} & \multicolumn{2}{|c|}{ Kroket } \\
\hline & & $\mathrm{n}$ & $\%$ & $\mathrm{n}$ & $\%$ & $\mathrm{n}$ & $\%$ \\
\hline 1 & Baik (>50\%) & 28 & 93.0 & 26 & 87.0 & 30 & 100.0 \\
\hline 2 & Kurang Baik (<50\%) & 2 & 7.0 & 4 & 13.0 & 0 & 0.0 \\
\hline 3 & Rata-rata penerimaan (\%) & \multicolumn{2}{|c|}{85.9} & \multicolumn{2}{|c|}{77.7} & \multicolumn{2}{|c|}{88.9} \\
\hline
\end{tabular}

Tabel 5. Sebaran Tingkat Kesukaan terhadap Kudapan (\%)

\begin{tabular}{llcccccc}
\hline \multirow{2}{*}{ No } & \multirow{2}{*}{ Tingkat Kesukaan } & \multicolumn{2}{c}{ Brownies } & \multicolumn{2}{c}{ Pia } & \multicolumn{2}{c}{ Kroket } \\
\cline { 2 - 8 } & & $\mathrm{n}=30$ & $\%$ & $\mathrm{n}=30$ & $\%$ & $\mathrm{n}=30$ & $\%$ \\
\hline 1 & Sangat tidak suka & 0 & 0 & 0 & 0 & 0 & 0 \\
2 & Tidak suka & 0 & 0 & 0 & 0 & 0 & 0 \\
3 & Biasa & 4 & 13.3 & 15 & 50 & 2 & 6.7 \\
4 & Suka & 24 & 80 & 13 & 43.3 & 26 & 86.6 \\
5 & Sangat Suka & 2 & 6.7 & 2 & 6.7 & 2 & 6.7 \\
\hline
\end{tabular}

tingkat substitusi tepung sukun maka nilai protein, lemak, dan serat kasar akan semakin menurun.

\section{Analisis Daya Terima dan Kesukaan Anak Sekolah}

Uji daya terima yang dilakukan dalam penelitian ini adalah kesanggupan anak usia SD yang berusia 10-11 tahun untuk menghabiskan ketiga jenis kudapan sesuai dengan takaran saji berdasarkan energi dan protein yang disyaratkan dalam PMT AS. Berat produk brownies adalah $74 \mathrm{~g}$ atau 2 potong sedang untuk mencukupi persyaratan PMT-AS, berat pia $80 \mathrm{~g}$ atau 3 buah untuk mencukupi persyaratan PMT-AS, sedangkan produk kroket adalah $67 \mathrm{~g}$ atau 2 buah. Tabel 3 menyajikan data jumlah kalori dan protein yang didapatkan dari kudapan per takaran saji.

Analisis daya terima dan kesukaan ini dilakukan di SDN Rama 1 Kota Tangerang. Jumlah subjek adalah 30 anak. Daya terima diukur dengan cara menimbang jumlah sisa makanan yang tidak habis dimakan. Daya terima dikelompokkan menjadi dua kategori yaitu baik dan kurang. Produk kudapan memiliki daya terima yang baik, apabila konsumsi $>50 \%$ dan kurang baik jika konsumsi $<50 \%$ dari makanan yang disajikan. Secara keseluruhan, $85 \%$ panelis memiliki daya terima yang baik terhadap kudapan yang disajikan. Tabel 4 menyajikan sebaran hasil daya terima kudapan. Tabel 4 menunjukkan dari keseluruhan produk yang disajikan, sasaran dapat menghabiskan rata-rata $85.9 \%$ produk brownies, 77.7\% produk pia, dan $88.9 \%$ produk kroket. Selain daya terima, dilakukan pula analisis kesukaan terhadap kudapan yang disajikan dengan menggunakan formulir uji hedonik yang terdiri dari 5 skala. Sebaran kesukaan panelis terhadap kudapan disajikan pada Tabel 5. 
Pratiwi dkk.

Data hedonik terhadap kudapan menunjukkan bahwa keseluruhan panelis menyukai produk kudapan terpilih berbahan dasar tepung sukun. Persentase penerimaan dihitung dari panelis yang memberikan jawaban biasa hingga sangat suka. Produk dengan tingkat kesukaan tertinggi adalah kroket. Hal ini dapat dilihat dari persentase panelis yang memilih suka dan sangat suka sebesar $94.3 \%$ dari keseluruhan.

\section{KESIMPULAN}

Kandungan zat gizi tepung sukun hasil analisis terdiri dari kadar air 9.2\%, abu 1.9\% (bb), lemak $0.38 \%(\mathrm{bb})$, protein $2.83 \%$ (bb), karbohidrat $85.65 \%(\mathrm{bb})$. Tepung sukun dibuat menjadi 3 jenis kudapan dengan cara pengolahan yang berbeda, yaitu brownies kukus, pia (panggang), dan kroket (goreng). Kudapan dibuat dengan mempertimbangkan beberapa hal, yaitu kemampuan tepung sukun mensubstitusi kudapan minimal 50\%, kudapan tersebut diolah dengan cara yang berbeda (dipanggang, digoreng, dan dikukus), dan keefektifan kudapan tersebut untuk memenuhi kebutuhan energi dan protein PMT-AS. Brownies dibuat dengan formulasi $70 \%, 80 \%$, 90\%, dan $100 \%$. Pia dan kroket dibuat dengan formulasi $50 \%, 60 \%, 70 \%$, dan $80 \%$. Hasil uji daya terima terhadap sasaran menunjukkan bahwa $85 \%$ anak sekolah memiliki daya terima yang baik terhadap kudapan yang disajikan dan $100 \%$ menyukai seluruh jenis kudapan. Penelitian serupa diharapkan dapat mengembangkan jenis produk kudapan lain berbahan dasar tepung sukun, seperti sereal ataupun cookies yang dapat memenuhi kebutuhan gizi anak sekolah sehingga dapat mencegah masalah kekurangan energi dan protein.

\section{DAFTAR PUSTAKA}

Akanbi TO, Nazamid S, \& Adebowale AA. 2011. Breadfruit starch-wheat flour noodles: preparation, proximate compositions, and culinary properties. International Food Research Journal 18, 1283-1287.
Adebayo SF \& Ogunsola EM. 2005. The proximate analysis and functional properties in fortified instant pounded yam flour. Global Journal of Science Frontier Research Biological Science, 5(7), 419-424

Alice AO, Ashudahuni OF, Rahman A, \& Kayode A. 2012. Proximate composition and sensory qualities of snacks produces from breadfruit flour. Global Journal of Science Frontier Research Biological Science, 12(7), 310-319.

Golden KD \& Williams OJ. 2010. The amino acid, fatty acid, and carbohydrate content of Artocarpus altilis (breadfruit); the white cultivar from the west indies. ISHS Acta Horticulture $757,251-262$.

Olandujoye IO, Ologhobo AD, \& Olanlyi CO. 2010. Nutrient composition, energy value, and residual anti-nutritional factors in differently processed breadfruit (Artocarpus altilis) meal. African Journal Biotechnology, 9(27), 4259-4263.

Olaoye OA, Onilude AA, \& Idowu OA. 2006. Quality characteristic of bread produced from composite flour of wheat, plantain, and soybean. Afri. Journal Biotechnology, 5(11), 11021106.

Omobuwajo TO. 2003. Compositional characteristics and sensory quality of biscuit, prawn crackers, and fried chips produced from breadfuit (Artocarpus altilis). Journal Innovative Food Science and Emerging Technologies, 4(2), 219-225.

Taylor MB \& Tuia VS. 2007. Breadfruit in the pacific region. ISHS Acta Horticulture 757, 43-50.

Tim Koordinasi PMT-AS Pusat. 2010. Pedoman Pelaksanaan Penyediaan Makanan Tambahan Anak Sekolah Tahun 2010. Tim Koordinasi PMT-AS Pusat, Jakarta.

Widowati S. 2003. Prospek Tepung Sukun untuk Berbagai Produk Makanan Olahan dalam Upaya Menunjang Diversifikasi Pangan [makalah]. Program Pasca Sarjana, Institut Pertanian Bogor, Bogor. 